\title{
Goddess of the Orient: Exploring the Relationship between the Persian Goddess Anahita and the Sufi Journey to Mount Qaf
}

\author{
Faranak Mirjalili
}

Citation: Mirjalili, Faranak. 2021 Goddess of the Orient: Exploring the Relationship between the Persian Goddess Anahita and the Sufi Journey to Mount Qaf. Religions 12: 704. https://doi.org/10.3390/ rel12090704

Academic Editors: Milad Milani, Zahra Taheri and Aydogan Kars

Received: 13 July 2021

Accepted: 19 August 2021

Published: 30 August 2021

Publisher's Note: MDPI stays neutral with regard to jurisdictional claims in published maps and institutional affiliations.

Copyright: (C) 2021 by the author. Licensee MDPI, Basel, Switzerland. This article is an open access article distributed under the terms and conditions of the Creative Commons Attribution (CC BY) license (https:/ / creativecommons.org/licenses/by/ $4.0 /)$.
Religious Studies, Center for the History of Hermetic Philosophy and Related Currents, University of Amsterdam, 1012 WX Amsterdam, The Netherlands; faranak.mirjalili@student.uva.nl

\begin{abstract}
This paper explores the possible connections between the Persian Goddess Aredvi Sura Anahita and Sufi cosmology. How can we trace images, symbols and functions of the goddess in the symbolic journey to Mount Qaf in Sufism? The research question was posed by the author after a collision of mystical experiences and dreams with the figure of Anahita while being on the Sufi path. The paper offers a linguistic, scriptural and hermeneutic analysis of Anahita in the Avesta and her role in Zoroastrian cosmology, while looking at the symbolic importance of Mount Qaf and the figure of Khezr in Sufism. The comparative study draws on the work of Henry Corbin and Shahab al-Din Sohrawardi to explore the threads between these two ancient Persian traditions.
\end{abstract}

Keywords: Aredvi Sura Anahita; Sufism; Mount Qaf; Divine Feminine; Xvarnah; Khezr; mystical experience

\section{Introduction}

Amongst the contemporary rising interest for the re-discovery of the Divine Feminine has been also a growing interest to study and research the ancient Persian Goddess Aredvi Sura Anahita. The unique research element of this goddess is that she was not exiled but included in the Zoroastrian cosmology and sacred scriptures. Moreover, she held an important role assisting Ahura Mazda himself, the Zoroastrian Godhead. Her role was so significant that when we study the scriptures carefully, we can read that Ahura Mazda was in fact himself dependent upon the blessings and guiding force of the goddess, to bring his religion to humanity through his prophet, Zarathushtra.

For this paper, I will explore the figure of Anahita through first elaborating on two personal experiences I had with a figure named Anahita. These initial encounters coincided with the year that I came to the Naqshbandi Sufi order of which I became a student and practitioner. The parallel and synchronistic experiences I had in the subsequent years with the figure of Anahita as well as classical Sufi experiences, made me question and research their interconnectivity and symbolic relationship of the two. This paper culminates the first part of this research.

Through both a textual and historical study, we will explore the goddess' name and role in the Zoroastrian scriptures. Furthermore, I will draw on the work of Henry Corbin (1903-1978) to explore the significance of the goddess in the Zoroastrian cosmology.

Henry Corbin was born in Paris and came into contact with Louis Massignon (18831962), director of Islamic studies at the Sorbonne. When Massignon gave him a volume of the work of Sohrawardi, he said "through my meeting with Sohrawardi my spiritual destiny for the passage through this world was sealed. Platonism expressed in the terms of Zoroastrian angelology of ancient Persia, illuminated the path that I was seeking". ${ }^{1}$ He went to Iran in 1939, and later also Istanbul, to immerse himself in Islamic and Persian mysticism where he spent much of his time studying and translating the work of Sohrawardi. He succeeded Massignon in the Chair of Islamic studies at the Sorbonne in 1954. He wrote his three major works in the same decade, Creative Imagination in the Sufism of Ibn Arabi (1969), Spiritual Body and Celestial Earth (1960) and Avicenna and the Visionary Recital (1960). 
Corbin only wrote a few passages about Anahita, and in each of them she is described as an important deity in Zoroastrianism:

"There is in Eran-Vej a mountain called Hukairya (Hugar, the very high), a mountain which is as high as the stars, and from which pours down the torrent of the heavenly Waters of Ardvi Sura Anahita, the High, the Sovereign, the Immaculate, a torrent possessing a Xvarnah as great as all the Waters together which flow upon the Earth. There it is that the earthly abode of the goddess of the heavenly Waters is imagined. She thus appears as the paradisal source of the Water of Life. Marvelous plants and trees grow in or around this wellspring, and above all the white Haoma, "Gaokarena", of which it is said: He who partakes of it becomes immortal. That is why the Elixir of immortality will be made from this at the moment of the final Transfiguration. The tree which cures all ills and "in which are deposited the seeds of all plants", grows next to the white Haoma. Indeed, the fertility of all beings in all their forms depends on the goddess or feminine Angel Ardvi Sura Anahita" (Corbin [1960] 1977, p. 26)

The exploration of the goddess will be followed by a comparative study on the Sufi journey to Mount Qaf, the emerald green mountain that marks the arrival of the traveler in Sufi cosmology. I will then discuss the Sufi archetype of Khezr, his significance for Sufis and the symbols and roles associated to him. Finally, we will explore the Zoroastrian Light of Glory (Xvarnah) of which the scriptures say that Anahita is the guardian and keeper of. This Light of Glory is the prophetic light that leads Zarathushtra to Ahura Mazda and it is the divine grace that he needs on his journey.

\section{Personal Experience}

For the context of this paper, I have chosen to elaborate the personal impetus and context that impelled me to explore the relationship between this ancient goddess and Sufi symbolism. I will share one hypnagogic ${ }^{2}$ dream and one mystical experience, both with the figure of Anahita. These experiences came to me in the same year that I met a Sufi teacher (shaykh) from a Naqshbandiyya-Mujaddidiyya order. ${ }^{3}$ It was also the same year that I started my training as a Jungian Analyst and was in the process of psychoanalysis myself. I was familiar with the idea of the personal and collective unconscious, archetypes and various myths and deities from around the world though was not yet familiar with any goddess figures from my own Persian heritage.

My interest for Sufism was an intuitive one, rather than an intellectual pursuit, thus I had not yet familiarized myself with Sufi doctrine or studies. The way I was led to my Sufi teacher was through a series of synchronicities and dreams as I was not looking for a teacher or a Sufi order at the time. The dreams and experiences with a figure that named herself Anahita happened a couple of months before I was to find my way to a Naqshbandiyya-Mujaddidiyya order. It is interesting to note that all of my experiences with Anahita have happened in an in between waking state, the so-called hypnogogic state:

The first time this feminine presence appeared to me, I was half asleep in a state of agitation, my body was sweating and I was in an overall state of discomfort and unease. I was feeling a presence with me that was keeping me half awake and yet I didn't know what or whom it was. At a certain point I could feel it was a feminine presence and I recognized it as Persian and a familiar sense came over me, as if she was some far distant ancestor I did not know. In that hypnagogic state I asked 'who are you?' and a voice answered 'Anahita'. 'That is a Persian female name' is all I knew and thought. Then, I went into a dream-vision state in which I was shown a narrative through a series of images that was accompanied by a strong physical sensory awareness. ${ }^{4}$

The images shown to me during the vision that followed the experience eventually became one of the most important dreams ${ }^{5}$ in my psychoanalytical process which opened up an important and psychological untangling from the so-called negative animus. ${ }^{6}$ It goes 
beyond the scope of this paper to go into that dream and its psychological interpretation. However, it is significant to mention that this dream and its visceral bodily experiences opened the gateway to the relationship that was to be established with the feminine archetype, which is in line with the Jungian thought of the feminine individuation process. (Jung [1937] 1959, par. 490).

In the next days and months, I started researching Anahita and to my surprise immediately found out that Anahita was a Great Mother or Goddess figure in ancient, preZoroastrian Persia and a Zoroastrian Angel-Goddess. My exploration of Anahita and deepening interest in Sufism started to unfold parallel to each other, though I was not conscious of this at the time. It was not long after meeting the teacher of the Naqshbandi order and practicing the heart-meditation and practice (zikr) of this Sufi Order, that Anahita again revealed herself to me, this time in a very different way.

In that hypnagogic sleep-waking state I felt my heart whirl open and a vibrational field enter my body. It was unlike anything I had ever experienced before. ${ }^{7}$ Its intensity gripped every cell in my body and it was beyond my control, doing, or will. All I know is that there was a presence with me again and I witnessed myself asking the same question: "Who are you?" It again answered, but this time in the same vibrational field and frequency that was running through my body. The vibration spoke thoroughly: A-N-A-H-I-T-A. The slow vibrational presence of the letters encompassed my whole body. I was in what I can only describe as awe. I was conscious enough to recognize her as the feminine presence that had visited me before. The recognition helped me trust what was happening to my body and allow the vibrations to remain for a short amount of time, though I have no awareness of time and how long the encounter actually took. ${ }^{8}$

These visitations continued over the course of the next years, as did my experiences on the Sufi path. And so my curiosity for this feminine presence grew stronger: Who is Anahita? What is her connection to the (spiritual) heart and to Sufism? The questions lead me to finding historical links between this ancient goddess and the Sufi journey, more specifically the quest to Mount Qaf. At the time, there was only a few contemporary pieces of literature on Anahita. In recent years more has been published and fortunately there has been an increasing academic and anthropological interest in the study of this ancient Persian goddess.

\section{Aredvi Sura Anahita}

Anahita is a pre-Zoroastrian water goddess of Persia who was widely venerated during the Achaemenid (7300-330 BCE) and Sassanian (224-651 CE) times (Boyce 1967, p. 37) with the earliest material evidence currently known dating back to the Median Period (c. 1100-c. 550 BCE). ${ }^{9}$ What is unique about Anahita is that she did not disappear with the monotheistic emergence of religion that started with Zoroastrianism in Persia. She was incorporated into the Zoroastrian pantheon and angelic hierarchy as an Angel-Goddess and became venerated as a yazata: an angel "worthy of worship". For the purpose of this paper, I will focus mainly on the descriptions we have of Anahita from the Zoroastrian scriptures. She became known in the Avesta, the sacred scriptures of Zoroastrianism, as Aredvi Sura Anahita. She therefor occupies an important place in the history of religion as a bridge between the matriarchal and patriarchal era as she is one of the few goddesses that has been integrated into an orthodox faith (Boyce 1982, p. 202).

If we look at the linguistic translation of Aredvi Sura Anahita, there seems to be a general consensus about the second adjective Sura, which is translated as 'mighty' or 'strong' (Saadi-Nejad 2021, pp. 46-49). The first adjective, Aredvi is often translated as 'moist' (Ibid, pp. 45-46) or 'the moist one' but not all scholars agree on this translation as some refer to a dialectic translation from the Avestan 'aredra' which would translate as 'the competent one' or 'she who succeeds' (Ibid, p. 46) (Kellens 2002, p. 322). 
Anahita has generally been translated from the Avestan language as 'immaculate' or 'pure' ('an-ahita' translated as 'not polluted' or 'not-soiled' (Nabarz 2013, p. 118). Pirart suggests in his essay on the linguistic analysis of Anahita's name and role in the Avesta that a more specific translation would be "the one who cannot be obscured or affected [by darkness or pollution]" (Pirart 2003, p. 201). I adhere to this translation and interpretation as it seems closer to her nature. Namely, it takes the emphasis off the virgin-like interpretation of Anahita as 'immaculate' or 'pure' into a powerful deity that is the very Source of Life itself-a source that cannot be polluted or affected by any shadow forces within creation. This aspect would make her most fitting for the role as the holder of the Zoroastrian Light of Glory, the Xvarnah. I will go into a more in-depth exploration of the Xvarnah later in this paper. For now, I would like to refer to the term as it is used and defined by Corbin: "It is the all-luminous substance, the pure luminescence of which Ohrmzad's (Ahura Mazda's) creatures were constituted at their origin. ${ }^{10}$ It is the Energy of sacral light which gives coherence to their being ..." (Corbin [1960] 1977, p. 13). Corbin continues to elaborate on the "eschatological hope" this Light is associated with as it is to ensure the Earth Angel Zamyat, is able to ensure the transfiguration and renewal of the Earth. (Yasht 19.11).

An alternative translation has been argued by scholars Kellens and Oettinger, who translated Anahita as 'unrestrained' (Kellens 2002, p. 322) or 'unbound' and 'like her original nature as torrential river' (Kellens 2002, p. 322; Oettinger 2001) as argued by Saadi-Nejad in her linguistic analysis of the varieties of translations for the goddess' name (Saadi-Nejad 2021, p. 47). For this paper, I propose the following translation and interpretation for the goddess: 'the Mighty, Unrestrained Torrential River'.

This torrential river is not only seen as an earthly river, but as a celestial one (Pirart 2003, p. 200), sometimes referred to as the symbolic Milky Way (celestial nourishment) itself (Nyberg and Schaeder [1938] 1896; Saadi-Nejad 2021, p. 53). This view of Anahita is a significant one for giving the Feminine back her place in the Celestial spheres, as to not only associate her to the earthly and material planes. The Zoroastrian God Ahura Mazda invites and pleas for Anahita to come down to the earth:

'Then she went forth, O Zarathushtra, Aredvi Sura Anahita,

from yonder stars,

to the Ahura-created earth

Then she spoke, Aredvi Sura Anahita".

-Yasht 5, paragraph 88

The fifth Yasht ("Aban Yasht" or "Hymn to the Waters") is one of the longest and most elaborate hymns where Anahita plays a significant role and is described thoroughly in the dialogue between Ahura Mazda and Zarathushtra. The Yashts (approx. 1000-600 BCE) are a collection of twenty-one devotional hymns to the yazatas, preserving the Young Avestan oral tradition. In this dialogue, we find a remarkable passage that illustrates the significance and importance of Anahita. In paragraph 18 of Aban Yasht (Yasht 5), Ahura Mazda makes a boon and asks Anahita to guide Zarathushtra into his religion.

"Grant me this, O good, most beneficent Ardvi Sura Anahita!

That I may bring the son of Pourushaspa, the holy Zarathushtra,

to think after my law, to speak after my law, to do after my law!"

-Yasht 5, paragraph 18

In this significant passage, the Zoroastrian God is dependent upon the blessings of the Goddess for bringing his religion to his prophet. He is even dependent on Anahita to have Zarathushtra follow him and his law. From a hermeneutic perspective, this would make Anahita into the bestower of prophecy, and a guide for Zarathushtra to Ahura Mazda himself. Symbolically, it is in this passage that we find the importance of the translation of Anahita as 'unbound' and 'unrestrained'. She who is unrestrained has the freedom and the ability to move between the levels of reality, connecting heaven and earth, prophet and 
his Lord. This particular function of Anahita will become important in our analysis and comparative study to the journey to Mount Qaf and the archetypal guide figure of Khezr.

In the beginning of the Aban Yasht, Ahura Mazda describes Aredvi Sura Anahita as the "life-increasing and holy, herd-increasing and holy, fold-increasing and holy, wealthincreasing and holy, country-increasing and holy" who is "worthy of praise" ${ }^{11}$ She purifies the wombs of all females and the seeds of all males, providing milk in the breasts of the mothers "in the right measure and quality" ${ }^{12}$ Her waters are as large as "all the waters upon the earth" that originate from her dwelling place that run from the high Hukairyra ${ }^{13}$ down to the great sea Voroukasha upon which the world rests. Thus, this gives Anahita a dwelling place that is at the peak of the highest mountain from where she flows and nourishes the entire world. In her dwelling place, she "reigns over a large Fortune"14, the Xvarnah, or Light of Glory. This makes the goddess both the keeper, protector and nourisher of life on the material plane as well as the guiding celestial—and as we have seen, prophetic-light of God. Her role in the prophetic tradition cannot be underestimated nor overlooked, as Corbin writes:

"Furthermore, we should never lose sight of the eschatological role of Aredvi Sura (parallel to the primordial role of Spenta Armaiti ${ }^{15}$, whose helper she is) in preserving the Xvarnah of Zarathushtra in the waters of the mystical lake, with a view over the conception of the final savior who will be brought into the world $[\ldots]$. All these figures give substance to the idea of a feminine Divinity whose presence is precisely in accord with the characteristic features of Mazdean religious feeling. We also wish to point out that Joseph Campbell, recently indicated how one could discover, in the Zoroastrian dualist reform, the resurgence in Iran of religious factors that belong to the pre-Aryan matriarchal world" (Corbin [1960] 1977, pp. 278-288 n 46).

In the same commentary Corbin reminds us that the "supreme God" of the Aryans Ohrmzad (Ahura Mazda) is in fact a priest (Yasht 1.12), but "how is it possible that he has become the priest of the goddess and address prayers to her?"16 He concludes that this important Yasht, as well as the importance of the role of other Feminine Angels in the Zoroastrian cosmology create a justifiable hypothesis that the early Zoroastrians community lived in a matriarchal system. ${ }^{17}$

Thus, Anahita as an Angel-Goddess is not only the nourisher and sustainer of life on the material, earthly plane (in her role as fertility goddess) but also a celestial nourisher, protectress of Divine Glory and a guide for the prophet. Furthermore, she holds an important role in the transfiguration of the Earth and is closely involved as nourisher, protector and helper of the Earth Angel (or Sophia) Spenta Armaiti.

Even though in the Avestan scriptures she is still created by Ahura Mazda himself, we cannot but conclude to give her a more equal position when we look at the culmination of all these attributes, roles and responsibilities that make Anahita into nothing less than the feminine aspect of the Godhead. ${ }^{18}$

\section{Sufi Cosmology \& the Journey to Mount Qaf}

Mount Qaf in Sufi cosmology is known to be the mythical or cosmic mountain that encompasses the earth (Jalāl and Chittick 1983, p. $356 \mathrm{n} .11$ and p. $357 \mathrm{n}$. 5). It is the dwelling place of the archetypal figure of the Simorgh (Persian phoenix), symbolizing the Sufi saint or the one who has made the journey back 'home' (Corbin [1990] 1998, p. 157). Henry Corbin describes Mount Qaf as the cosmic pole, the emerald rock or where the world of Hukairya (Al-Malakut) begins (Corbin [1960] 1977, pp. 71 and 28). It is equated with the physical geographical mountain of Alborz in northern Iran (Ibid, p. 74), within which the highest mountain of Iran is based, Mount Damavand. While Alborz holds both a mythical and geographical significance to Persian culture and literature, Mount Qaf and Hara Berezait ${ }^{19}$ hold a purely imaginal and cosmological significance to respectively Sufism and Zoroastrianism. Both the places refer to the same mythical mountain of revelation 
where the Spring of Life can be found. It is the imaginal locus between the worlds, where the visible and invisible spheres meet. Shahab Al-Din Sohrawardi (1154-1191), the great Persian philosopher and mystic, named this place Na-Koja-Abad, which translates as "the Abode of No-Where" ${ }^{20}$

"This, Sohrawardi declares, is the world to which the ancient Sages alluded when they affirmed that beyond the sensory world there exists another universe with a contour and dimension and extension in a space [ ... ]. It is the "eighth" clime or keshvar, the mystical Earth of Hurqayla ${ }^{21}$, with emerald cities; it is situated on the summit of the cosmic mountain, which the traditions handed down in Islam call the mountain of Qaf" (Corbin [1978] 1994, p. 43)

In Sohrawardi's work, we find the repetitive motif of the journey to Mount Qaf, where the seeker will find the Spring of Life which marks a 'return to the Orient' and a freeing from the 'exile in the Occident'. This Orient is not the geographical one, but a symbolic arrival at the highest peak and center of the cosmic mountain; the Emerald Rock at the summit of Mount Qaf (Ibid, p. 44). It is in this center that the Spring of Life is found. One who bathed in this Spring is reborn and "becomes like Khidr" (Corbin 1971, pp. 142, 144).

As we have seen above, at the summit of the older Avestan mount Hara Berezaiti there is also a Spring of Life-embodied by the Goddess Angel Aredvi Sura Anahita-who possesses the Xvarnah, the Zoroastrian Light of Glory (Corbin [1960] 1977, p. 26). It is in the waters of Anahita that are held the seeds of the primordial man Yima, or according to the Avesta the seeds (or gold, light) of Zoroaster and his Saoshyant (offspring) who will serve at the end of our Aeon (Ibid., p. 49). Connections between these ancient mythological mountains are not difficult to find in the writings of Corbin as the work of Sohrawardiwhom Corbin's lifework is partly based on-is rich with these ancient Persian esoteric motifs and connections. It is in his work that these traditions come together and find each other in the various overlaying motifs.

\section{Khezr: The Green One}

One of the figures in Sufism associated with the 'Water or Spring of Life' is Khezr. ${ }^{22}$ Let us look closer at this figure and his possible symbolic relationship to Anahita. Khezr is known by Islamic and Sufi scholars as the archetypal guide for the seeker. Tom Cheetham writes: "Khidr is the personal guide, and Corbin says, equivalent to the Paraclete and the Hidden Imam, to the Christ of the Cross of Light; he is the Verus Propheta, the inner guide of each person, the celestial Anthropos and Angel of Humanity whose appearance to every person is each time unique" (Cheetham 2005b, p. 122). This description, especially the latter, gives us a reference to the reflective and perhaps even androgynous nature of Khezr, which welcomes a comparative study on the connections to goddess Anahita whose very nature as water is reflection. Sohrawardi makes a clear statement about what it means to be a disciple of Khezr: to be initiated by him is to become him (Corbin [1969] 1997, pp. 60-61). This means that Khezr's role is to lead each disciple to him or herself, and thus own unique individuality. He is the colorless guide who wears the green mantle of truth (haqiqa), that will reveal a different note and image to the unique spirit of the time, place and people. Why this is especially important for the experience of the Feminine nature of the Godhead, I will elaborate on later in this paper.

In the Qur'an (Sura 18: 60-82) Moses asks God if there is anyone more knowledgeable than him, upon God confirms that he can be found 'where the two seas meet' and where the caught fish that they have brought with them comes alive and swims away. Moses sets out to find him and when he eventually does at the juncture of the two seas, he asks to be his companion for a while. Khezr warns that he will not be able to bear with him, but Moses insists. As they travel, Moses becomes more agitated with Khezr's seemingly unjust (sinking a boat, killing a boy) actions until they eventually part, only after Khezr explains to him the hidden reasons behind his actions, invisible to the first gaze on the situations they encountered (Ibn Kathir and Azami 2003, pp. 131-34). The story illustrates the place from where Khezr operates, which is a place of polarity and paradox, held within Divine will. It 
is a symbolic reference to his transcendent function. He is the hermeneutic guide figure who is "one of our servants, whom we have endowed with our grace and our wisdom" (Sura 18: 65). The place he can be found is the place where two worlds meet (the seen and the unseen) and where the dead fish, symbolising the exoteric knowledge comes alive into an esoteric one or gnosis. He is sometimes referred to as the 'prophetic soul' within the human (Jalāl and Barks 1995) or the organ of perception that can be accessed through the eye of heart (ayn al-qalb) through which one sees and encounters God directly (Markwith 2009, p. 111). Seyyed Hossein Nasr writes that Khezr is regarded as the guardian of the fountain of life and the ever present initiatory function in the Islamic tradition (Seyyed 1989, pp. 89 and 108 n. 10):

" ... Man must therefor seek the fountain of life, led in this quest by the figure whom Islamic esoterism call Khidr, the guide upon the spiritual path, the representative and symbol of the Eliatic function which cannot but be always present. Having drunk of the water of immortality, which is also the elixir of Divine knowledge, man regains his original consciousness and primordial abode. His wandering ceases and he arrives after his long cosmic journey at that from which his true self never departed" (Ibid., p. 277)

\section{Khezr and Anahita}

The likeness between the description, symbolism and role of Khezr and Anahita is so close that a connection between these two figures can be assumed. What this connection entails exactly, is a subject for more in-depth research and discourse. It has been argued by Kathryn Babayan that it is one and the same figure, especially when we study Khezr from the cultural and anthropological perspective, where he is known as a fertility saint and women evoke him at childbirth or when they have the wish for a child (Babayan 2002, p. 368). Similarly, the places of goddess worship that once belonged to Anahita, slowly converted into Muslim shrines of worship of 'real' women from legends that spread after the Arab invasion. Boyce, in her well-known essay Bibi Shahrbanu and the Lady of Pars, shares in her field research the transformation of these sacred sites from the worship of a deity to the worship of a deceased holy person (or hero) and in some cases Khezr, and the underlying religious reasons (Boyce 1967, pp. 30-44). Although I agree that the earthly aspects of the goddess have gone underground, or rather undercover, partly through the invocation and worship of the figure of Khezr, I suggest a slightly different view on the esoteric relationship between Khezr and Anahita.

If indeed, Khezr is the guardian of the fountain or Spring of Life as argued by Nasr, or the archetypal guide figure toward this Spring, then Khezr could be seen as the personification of that aspect of the human soul that has the capacity to merge and unite with the Water of Life or the feminine 'ground of being' that underlies, protects and nourishes all of creation, known in ancient Persia as Anahita. In this merging, they are indeed one and the same guiding force that leads the innermost part of the human being home to the world of the soul. Perhaps this is symbolically best imaged in the relationship of the Sufi hoopoe bird and the great Simorgh (the Persian mythological bird or phoenix).

In one of Sohrawardi's works "The Incantation of Simorgh"23 we find a feminine ${ }^{24}$ description of the mythical Simorgh, who was first the 'hoopoe bird that set out on its journey to Mount Qaf'. Upon arriving there, she strips herself from all her feathers with her own beak, until the shadow of Mount Qaf would shine upon it for a certain time, transforming the hoopoe bird to the eternal Simorgh whose song awakens those who have fallen asleep. ${ }^{25}$

"Simorgh flies while immobile, she takes flight but covers no distance; she comes closer and yet there is no separation. She possesses every hue but has herself no color. Her nest is in the Orient but it is not absent from the Occident. She is involved in everything but not dependent on anyone. All knowledge is derived from the modulation of this bird, just like the sound of all musical instruments emanates from it". (Corbin 1971, p. 146) 
This description of Simorgh echoes many of the attributes of Anahita, who is the giver and sustainer of all of life, though unbound and unrestrained. Her dwelling place is the High Hara (Hara Berezaiti), the peak of the cosmic mountain where the color green abounds, but she flows down through a thousand channels into all the waters of the Earth (Yasht 5.4). As the water of life, she will reflect all colors, but has herself no color. And within her dwelling place is found the Haoma tree, the tree that possesses all the seeds of creation, and within her waters is kept the most important fire in Zoroastrian cosmology; the Xvarnah, the Light of Glory.

\section{Xvarnah-The Zoroastrian Light of Glory}

In the old Mazdean stories, as well as in the Avesta-the primary sacred texts in the Zoroastrian religion-it is the Xvarnah (or Farrah, Farnah, Farr or Khurrah ${ }^{26}$ ) that plays an important role in both the prophetic initiation of Zoroaster as well as the return to Primordial Man (Yima) or state of being. It is generally translated as the (celestial) Light of Glory or Victorial Fire (Corbin 1971, p. 53). As we have seen above, this Light is not only a personal, transcendent Light but a universal one that Zoroastrians worshipped and made sacrifices to (Yasht 19). It is the Light that has an "eschatological hope" as argued by Corbin (Corbin [1960] 1977, p. 13) and a significant role in the purification, renewal and restoration of the Earth from the powers of ignorance (Yasht 19.18). This is highly significant as Anahita is also known as the 'coworker' (hamkar) of the Earth Angel Spenta Armaiti who plays a key role in the preservation of the Xvarnah that is to bring forth, or activate, the archetypal hero of the final restoration (apokatastasis) within humanity (Ibid, p. 50).

In the second Volume of his magnum opus, En Islam Iranien (Corbin 1971), Corbin gives an in-depth analysis of the etymology, history and various definitions of this word, since there are various levels of Xvarnah to be studied in the ancient writings. We find the practical or royal Xvarnah or 'divine favour' that was granted to Kings and leaders as well as the more mystical and celestial dimension of the Xvarnah, which Corbin is more interested in. He compares the receiving of or 're-uniting' with the Xvarnah as the 'resurrected body of light' that can pass through 'Mount Qaf without difficulty'. It is this 'body' that becomes the organ of perception in the 'eighth clime (keshvar)'.

Corbin makes an in-depth comparative study between the Mazdean Xvarnah and Kay Khusraw's dwelling in the 'hidden castle ${ }^{27}$ and the Western Holy Grail ${ }^{28}$, whose analysis falls outside of the scope of this paper. ${ }^{29}$ After an elaborate analysis of the word Xvarnah, its historical context and a comparative study with the motifs of the Holy Grail, Corbin draws the following conclusion:

"So Kay Khusraw's mysterious castle, Kang-Dez-Behesht (Kang-Dez-Paradise) is itself erected in this 'eighth clime' where the city of Hurqalya belongs, i.e., the 'intermediate Orient'. City and castle make up the 'celestial pole', the sources of Xvarnah where the theophanies contemplated by the Sages of ancient Persia are born in an eternal aurora". (Corbin 1971, p. 113)

This comparison with the Holy Grail is indeed important to note, since the Holy Grail could indeed be another image of the Source or Water of Life found in Mount Qaf or the Zoroastrian Hara Berezaiti.

\section{Water and Light}

The links between the Xvarnah, held by Anahita and the symbolism of water is a significant one in our analysis. Corbin writes that water and light are traditionally interchangeable as sources of life and knowledge: "The Source is itself not an object of knowledge, but that which makes it gush forth". Thus, Anahita, as the container, source and torrential river of light can be seen the bestower of knowledge; she connects the seeker with the knowledge, making her into a benefactress and enabler of gnosis. This interpretation brings clarity to why Ahura Mazda, the almighty Mazdean God, would need the Goddess to guide his prophet Zarathushtra toward 'his good religion'. She has 
the power to both bring knowledge down from the 'belly (Pirart 2003, p. 200) or tongue (Saadi-Nejad 2021, p. 63) of Ahura Madza'30, the world of Light. She then holds, contains and reflect that Light to Zarathushtra and 'his offspring', which gives her the power to move and guide the prophet toward knowledge. Anahita, unbound and unrestrained to anyone, pure, clear and unpollutable, has the capacity to move anywhere without difficulty and reflect the Light of Glory to the seeker that is ready.

The links between Anahita as a water deity and water symbolism in Persian Sufism have also been made by Milad Milani in his book Sufism in the Secret History of Persia (2013) (Milani [2013] 2014) where he elaborates on the symbolic links between the two traditions:

In Persian Sufism, Anahid is a prevalent and subliminal feature. Here she is not invoked in name, but being "associated with the ocean" is metaphoric for the act of becoming the disciple of a master and of traversing the Sufi path. ${ }^{31}$ In the Sufi tradition, the ocean is temperament, the dangers contained within it, and the subtle rules that govern it govern the rules of engagement with the master of the path or, in effect, God. Traditionally, Zarathushtra received his revelation at dawn, at the foot of a riverbank during the Haoma (Soma) ceremony, whereby young priests would offer penitents to the waters (Aban). (Milani [2013] 2014, pp. 49-50)

\section{Conclusions}

Personal mystical experiences on the Sufi path that coincided with the appearance of a figure named Anahita in both my dreams and hypnagogic (sleep-waking) state were the impetus for an inquiry and research on the possible connections between the ancient Persian goddess Anahita and the Sufi journey. A textual and comparative analysis of the scriptures of the Avesta (Yasht 5) show that the goddess Anahita was not only incorporated into the Zoroastrian orthodoxy but has also been venerated as a highly significant Angel-Goddess that goes by the Avestan name Aredvi Sura Anahita. Her full Zoroastrian name implies that she is a 'mighty celestial torrent that is unrestricted, unbound and unpollutable'. She contains and preserves the most important Light in Zoroastrian cosmology: the Xvarnah, the Light of Glory. Anahita is not only an earthly Goddess who is responsible for fertility of women, men, soil and plants but she also plays a crucial role as a powerful deity that is responsible for preserving the celestial Light, that, in the words of Corbin carries "eschatological hope" (Corbin [1960] 1977, p. 13). She has an important role to play as a coworker (hamkar) of the Earth Angel Spenta Armaiti-the Persian Sophia-in the final restoration and renewal of the Earth according to Zoroastrian scriptures (Ibid., p. 50). She is the Goddess-Angel that preserves the 'seed' and Light of Zarathushtra and guides him to Ahura Mazda and his 'good religion'. She is therefor, a guiding force that Ahura Mazda needs in order to bring the prophet to himself (Yasht 5.18).

Furthermore, Anahita is described as a water deity in the Avesta and as the Source of Life that is situated at the highest point of the Zoroastrian mythological mountain Hara Berezaiti. It is this place that brings us to a very significant connection to Sufi cosmology and the journey to Mount Qaf. At the top of Mount Qaf is also situated the Water or Source of Life where the color green abounds and where the archetypal guide-figure of Khezr has his dwelling, the abode of which he is the guardian. Khezr is also known as the archetypal guide to those that are 'without a master' in Sufi literature. As the 'Green Man' he embodies the essential qualities of both heaven and earth and is the archetypal isthmus that comes forth out of-and guides the seeker into-the imaginal realm; the Mundus Imaginalis as described by Corbin, or the Source of Life at the summit of the mythical Mount Qaf. Here, Khezr can be seen as the 'embodiment' of the Zoroastrian Xvarnah, the Light of Glory that is the guiding Light which Anahita preserves. The connections between these two figures is worthy of in-depth research and further comparative study.

It is well-known and argued by scholars that ancient sites that once belonged to the era of Goddess worship or that were temples for Anahita slowly transformed in either Zoroastrian temples that later again became mosques or that became places of worship 
for legendary or holy women (Boyce 1967) that were said to have lived as humans, rather than a deity. Worship of an invisible Goddess slowly became unacceptable and started to disappear during and after the increasing orthodoxy of Zoroastrianism and the later Islamic conversion of Iran. Therefor the traces of the ancient goddess Anahita have been veiled by these later traditions, stories and symbols. It is thus of no surprise that Anahita could not be named explicitly in Sufi cosmology and literature. This does not mean however, as we have seen, that Anahita has altogether disappeared from these cosmologies as a living symbol and 'Goddess of the Orient'.

With the rise of female practitioners in many mystical traditions, including that of Sufism, it is becoming increasingly important from both a psychological as well as phenomenological perspective to acknowledge the feminine aspects and symbols of these traditions, as well as the feminine deities associated with the mystical quest. It is through the images, symbols and the names of these figures in our heritage that practitioners and seekers relate to the imaginal realm. As it is well known in depth-psychology, these universal guiding forces can appear in their feminine form in a woman's psyche. These symbols or apparitions will not be recognised and remain unacknowledged or even dismissed if they are only interpreted within the framework of masculine oriented religious symbolism and iconography. Fortunately for our research on Anahita, she has been well-preserved as-perhaps one of the few-Goddess 'Names' that made it from a matriarchal, pagan society into a monotheistic one. Therefore, she occupies a unique position in reflecting the importance of the Divine Feminine in religion and mysticism.

Funding: This research received no external funding.

Institutional Review Board Statement: Not applicable.

Conflicts of Interest: The author declares no conflict of interest.

\section{Notes}

Quoted in Jambet (1981, pp. 40-41). See T. Cheetham (2005a, pp. 16-17).

A hypnagogic state of consciousness is referred to the transitional state between wakefulness and sleep in which visions, images and bodily experiences (including the more common phenomena of 'sleep paralysis') can occur. Cognitive schools of psychology sometimes refer to this as a 'hallucination'. However, from a Jungian or depth-psychological perspective, these are inter-dimensional or archetypal experiences that can transcend the psyche. These are sometimes referred to as 'psychoid' experiences, see Jung ([1947] 1960, para. 368).

I became an official student of this order in the subsequent years.

Diary entry from a dream-journal (no. 1) kept during my Jungian training.

More on the importance of dreams as a connection to the sacred during Jungian psychoanalysis: Jung ([1934] 1970, pp. 304, 864).

Carl Jung coined the masculine component within a woman's psyche 'animus' and the feminine within a man 'anima'. Coming to terms with the 'negative animus' is one of the difficulties in a woman's psychoanalytical journey. For more on the concepts of animus see: (Jung [1955] 2008).

7 The experience of a 'presence' via the heart correspond to Sufi mystical experiences 'through the power or intend of the heart' (himma), see Corbin ([1969] 1997, pp. 219-20).

8 Diary entry from a dream-journal (no. 3) kept during my Jungian training.

9 Saadi-Nejad, Anahita, p. 120.

10 "From it Ahura Mazda has created the many and good ... beautiful, marvellous ... creatures, full of life, resplendent". (Yasht 19.10)

Yasht 5.1 as translated in Nabarz (2005, p. 194).

Yasht 5.2-3.

This is also known as Hara Berezaiti (the High Watchpost) or the 'highest peak on high Hara', (Yasht 10. 88) and see also Boyce (1982, pp. 136-37).

Yasht 5.96, see for full translation Saadi-Nejad (2021, p. 55).

Corbin equates Spenta Armaiti to the Western Sophia, or the Angel-Soul of the World according to Zoroastrianism. Thus, Anahita is clearly related but not equated with the Soul of the World, or the Anima Mundi. This gives Anahita yet again an important differentiating role in the cosmology of the Divine Feminine. 
16 Here Corbin refers to Yasht 5.18 where Ahura Mazda prays to Anahita to lead Zarathushtra to him and have him "attach to him".

17 See also Nyeberg, Religionen des Alten Iran, pp. 252 ff., 271-72 (Nyberg and Schaeder [1938] 1896).

18 There are similarities between the role, function and description of Anahita with the Jewish Shekinah that are worthy for further research. See: Baring (2013, p. 49): "In this extraordinary cosmology, the Shekinah or the feminine face of the godhead is named as Cosmic Womb, Palace, Enclosure, Fountain, Apple Orchard and Mystical Garden of Eden. She is named as the architect of the worlds, source or foundation of the world, and also as Radiance, Word or Glory of the unknowable ground or godhead. [ ... ] This center expands or is sown as a ray of light into what is described in some texts as a sea of glory [ ... ]. From here it emanates as a radiant cascade, a fountain of living water, pouring forth light to create, permeate and sustain all the worlds or dimensions into being".

19 As mentioned in the Avesta, where the dwelling place of Anahita is.

20 Corbin $(1976$, p. 2). Henry Corbin, in this famous essay, translates Na-Koja-Abad as 'the Place of No-Where'. I suggest a more specific translation for the Farsi word abad. Translating it to 'abode' would be a more fitting translation as abad doesn't literally translate as 'place' but a 'place that has come alive, or habitable'. Therefor the 'Abode of No-Where' will give the reader the sense that this place has become a dwelling place for the seeker, a place where (s)he can reside. See Steingass (1892, p. 3).

21 Corbin uses here the term Hurqayla to refer to the 'Realm of Dominion' in Islamic cosmology, also referred to as 'Al-Malakut', the celestial or angelic realm. This is linguistically not the same name as the Zoroastrian Hukairya (meaning 'of good activity) which refers to the cosmic mountain Hara Berezaiti. The place that both terms refer to however, can be equated to each other as both refer to the realm of the imaginal, where the worlds of the seen and unseen meet.

22 Also known as Al-Khadir, Khidr, Khadr translated and known also as the Green or Verdant One.

23 Sometimes also translated as "The Shrill Cry of the Simurgh". See for an English translation: Shihabuddin Yahya Suhrawardi, The Philosophical Allegories and Mystical Treatises: A Parallel PersianEnglish text, trans. Wheeler Thackston, Bibliotheca Iranica, intellectual Series, No. 2 (Costa Mesa: Mazda Publishers, 1999), pp. 91-92.

24 Translations between a feminine and masculine pronoun differ. Henry Corbin refers to the Simorgh as 'she'. The original language (Farsi) in which it is written by Sohrawardi the word ou is used, which is neither feminine nor masculine, but can be either.

25 The figure and symbol of Simorgh appears throughout Persian mythology and literature, with the most famous story being a poem by Farid ud-Din Attar (1146-1221) called 'The Conference of the Birds' (1177) (Attar et al. 2011). This is a particularly influential and important story amongst Sufis.

26 These are a variety of names in the old Persian texts. Xvarnah is the original Avestan word, where Khurrah is the Persian derivative of. Farnah is from the old Aechemenids and Far and Farrah are both old Pahlavi names for this same Light of Glory.

27 Kay Khusraw is a legendary character in the epic of Shah-nameh and one of the most important heroic figures in Persian mythology. At the end of his heroic deeds, it is said that Kay Khusraw withdrew into a mystical castle called 'Kang-Dez', a place that heroes and saints withdraw to without physical death. The comparison Corbin makes is between Parcifal and Kay Khusrow.

28 Specifically, as it occurs in the work of Wolfram von Eschenbach (c. 1160/80-c. 1220), i.e., the tale of 'Parzival'.

29 For more see Corbin (1971, chp. 4).

30 Yacht 5.6 as translated in Pirart as 'belly' whereas Saadi-Nejad translates the same lines in the hymn as the 'tongue' of Ahura Mazda: "And I, Ahura Mazda, created her by the impetus of my tongue (speech?)". In both interpretations, Anahita is a substance or river that gushes forth out of the godhead as a current of light. This image corresponds to the role of the goddess as the guide to or enabler of gnosis or direct revelation.

31 As quoted in footnote by author: J. Nurbakhsh, "Associating with the Ocean: Becoming the Disciple of a Master", Sufi 50 (Nurbakhsh 2001), 18; “The Drop and the Ocean", in J. Nurbakhsh, Discourses on the Path (London 1996), 30-31. Nurbakhsh, of course, had adapted Rumi, in whose verse the analogy of water and reference to the "ocean" is a constant theme throughout; cf. $M, 5: 3853-9$ ("Love is an [infinite] Ocean, on which the heavens are [but] a flake of foam").

\section{References}

Atțar, Farid al-Din, Dick Davis, and Afkham Darbandi. 2011. The Conference of the Birds. New York: Penguin Books.

Babayan, Kathryn. 2002. Mystics, Monarchs and Messiahs: Cultural Landscapes of Early Modern Iran. Cambridge: Harvard University Press.

Baring, Anne. 2013. The Dream of the Cosmos: A Quest for the Soul. Dorset: Archive Publishing.

Boyce, Mary. 1967. Bībī Shahrbānū and the Lady of Pārs. Bulletin of the School of Oriental and African Studies 30: 30-44. [CrossRef]

Boyce, Mary. 1982. A History of Zoroastrianism. Leiden: E. J. Brill, vol. 2.

Cheetham, Tom. 2005a. The Prophetic Tradition and the Battle for the Soul of the World. Temenos Academy Review 8: 14-33.

Cheetham, Tom. 2005b. Green Man, Earth Angel: The Prophetic Tradition and the Battle for the Soul of the World. Albany: State University New York Press. 
Corbin, Henry. 1971. En Islam Iranien: Aspects spirituels et philosophiques. Vol. 2: Sohravardi et les Platoniciens de Perse. Paris: Editions Gallimard, English Translation by Hugo M. van Woerkom, 2003.

Corbin, Henry. 1976. Mundus Imaginalis: Or, the Imaginary and the Imaginal. Ipswich: Golgonooza Press.

Corbin, Henry. 1977. Spiritual Body and Celestial Earth: From Mazdean Iran to Shi'ite Iran. Translated by Nancy Pearson. Princeton: Princeton University Press. First published 1960.

Corbin, Henry. 1994. The Man of Light in Iranian Sufism. Translated by Nancy Pearson. New Lebanon and New York: Omega Publications. First published 1978.

Corbin, Henry. 1997. Alone with the Alone: Creative Imagination in the Sufism of Ibn 'Arabi. Princeton: Princeton University Press. First published 1969.

Corbin, Henry. 1998. The Voyage and the Messenger: Iran and Philosophy. Berkely: North Atlantic Books. First published 1990.

Imamduddin Ibn Kathir, and Rashad Ahmad Azami, transs. 2003, Stories of the Prophet (Qisas Al-Anbiya). Riyadh: Darussalam.

Jalāl, al-Dīn Rūmī, and C. Barks. 1995. The Essential Rumi. San Francisco: Harper.

Jalāl, al-Dīn Rūmī, and W. C. Chittick. 1983. The Sufi Path of Love: The Spiritual Teachings of Rumi. Albany: State University of New York Press.

Jambet, Christian, ed. 1981. Cahier de l'Herne No. 39: Henry Corbin. Paris: L’Herne.

Jung, Carl G. 1959. Collected Works 9: The Concept of the Collective Unconscious. Princeton: Princeton University Press. First published 1937.

Jung, Carl G. 1960. Collected Works 8: Structure E Dynamics of the Psyche, "On the Nature of Psyche". London: Routledge \& Kegan Paul. First published 1947.

Jung, Carl G. 1970. Collected Works 10: Civilization in Transition, "The Meaning of Psychology for Modern Man". Princeton: Princeton University Press. First published 1934.

Jung, Emma. 2008. Anima E Animus: Two Essays. Thompson: Spring Publications. First published 1955.

Kellens, Jean. 2002. "Le Probleme avec Anahita”. Orientalia Suecana 51: 317-26.

Markwith, Zachary. 2009. The Eliatic Function in the Islamic Tradition: Khiar and the Mahdi. The Journal of Sapiential Wisdom and Philosophy 6: 97-136.

Milani, Milad. 2014. Sufism in the Secret History of Persia. New York: Routledge. First published 2013.

Nabarz, Payam. 2005. The Mysteries of the Mithras: The Pagan Belief That Shaped the Christian World. Vermont: Inner Traditions.

Nabarz, Payam. 2013. Anahita, Ancient Persian Goddess and Zoroastrian Yazata. London: Avalonia Books.

Nurbakhsh, Javad. 2001. Associating with the Ocean: Becoming the Disciple of a Master. Sufi Journal Issue 50: 18.

Nyberg, Henrik Samuel, and Hans Heinrich Schaeder. 1896. Die Religionen des Alten Iran. Leipzig: Johan Conrad Hinrichs Verlag. First published 1938.

Oettinger, Norbert. 2001. Neue Gedanken über das nt-Suffix. In Anatolisch und Indogermanisch. Edited by Onofrio Car-ruba and Wolfgang Meid. Innsbruck: Institute for Sprachen und Literaturen der Universität Innsbruck, pp. 301-15.

Pirart, Eric. 2003. Les Parties Étiologiques de l'Ardvīsūr Bānūg Yašt et Les Noms de La Grande Déesse Iranienne. Indo-Iranian Journal 46: 199-222. [CrossRef]

Saadi-Nejad, Manya. 2021. Anahita: A History and Reception of the Iranian Water Goddess. London: Bloomsbury Publishing.

Seyyed, Hossein Nasr. 1989. Knowledge and the Sacred. Albany: State University of New York Press.

Steingass, Francis Joseph. 1892. A Comprehensive Persian-English Dictionary, including the Arabic Words and Phrases to Be Met with in Persian Literature. London: Routledge \& K. Paul. 